\title{
CHARACTERISTICS OF EMBEDDED PEAT IN COASTAL ENVIRONMENTS
}

\author{
Haider Al-Ani ${ }^{1)}$, Erwin $\mathrm{Oh}^{2}$, Gary Chai ${ }^{3)}$ \\ ${ }^{1,2)}$ School of Engineering, Griffith University, Queensland, Australia. \\ 3) Centre of Infrastructure and Engineering Management, Griffith University, Australia
}

\begin{abstract}
This study examines the engineering characteristics and properties of peat soils in coastal environments in Ireland, Italy, Malaysia, Netherlands, Turkey and USA. The engineering properties to be examined are consolidation characteristics, Atterberg limits, density, organic content, shear strength, and moisture content. Moisture content and organic content are good indication of the occurrence of peat soils because these parameters are inherently high in this soil type. In addition, peat soil is highly compressible and is known to be problematic for geotechnical construction. The peat layer has an adverse effect on the long-term settlement of road embankments. A case study of peat soil deposits in Surfers Paradise in Australia will be presented in the paper. Peat soil in the study area is embedded at depth ranging between R.L. -10 to R.L. $19.6 \mathrm{~m}$ below the ground surface and it has a thickness ranging from 0.1 to $7.0 \mathrm{~m}$ in some locations. It possesses low shear strength of between $30-40 \mathrm{kPa}$ and the moisture content can be up to $247 \%$. Four empirical equations have been established for the peat soils and they are compared with those published in the literatures.
\end{abstract}

Keywords: Peat, Organic Content, Consolidation, Atterberg Limits, Moisture Content.

\section{INTRODUCTION}

The term peat denotes soils with high organic content derived mainly from plant remains. It has a spongy consistency, dark brown to black colour, and organic odour. Remains of plant fibres occasionally are visible, but they may not be recognisable in the progressive process of decomposition. Peat soil is an accumulation of disintegrated plant remnants which have been preserved under condition of high water content and incomplete aeration [1]. Peat soil can also be defined as "generally unconsolidated organic material consisting largely of organic residues accumulated as result of incomplete decomposition of dead plant constituents under conditions of excessive moisture" [2].

Irrespective of the geographic location, peat soil accumulates wherever conditions are suitable, which is in areas with surplus rainfall and poorly drained ground [1]. Reference [3] stated that the formation of the organic materials is a result of the biochemical process. However, the accumulation process depends on the ecosystem and climate conditions. Peat soil is highly organic, extremely compressible and is known to be problematic for geotechnical purposes.

Peat soil exhibits exceptional geotechnical properties in comparison with those of inorganic soils such as sandy, silty or clayey soils. Peat soil has no precise definition among soil scientists and engineers. Soil scientists have defined peat soil as a soil with organic content greater than 35\%; however, geotechnical engineers define peat soil as soil with organic content greater than 20\% [1]. According to [4] peat soil can be divided into three main types for engineering purposes. First, amorphous - granular peats which have high colloidal minerals and appear like clay in grain structure where the inter-spaces water is kept locked in an adsorbed condition around particles. The other two peat soil types are fine-fibrous and coarse -fibrous peats, which hold the inter spaces water in the peat soil mass as a free water. These types are described as woodier peat soil.

It is generally accepted that the organic matter present in soils causes a detriment to their geotechnical and engineering qualities [5]. Many engineers consider peat soils as problematic soil because of their abnormal properties. These soils, according to [6] are geotechnically problematic and cause instability problems such as development of slip failure, local sinking, and massive primary and long term settlement even when load increases moderately, because of their low shear strength and high compressibility. Therefore, these soils are unsuitable for construction because they cannot support the foundations.

The development of the infrastructure of a country is an indication of economic prosperity. Therefore, the contribution of geotechnical engineering cannot be overemphasized. The objective of this paper is to review and examine the engineering properties of peat soil in selected countries. These countries are: Ireland, Italy, Malaysia, The Netherlands, Turkey, and the USA. In addition, a case study has been investigated in terms of the occurrence of the peat layer in Surfers Paradise, Australia. 


\section{PEAT EXISTANCE IN DEPOSITIONAL COASTAL ENVIRONMENTS}

\subsection{Peat Occurrence in Ireland}

Peat soil failures are common throughout the world especially in British Isles where $80 \%$ of reported failures have occurred [7]. The historical record of peat soil failure in Britain showed that there were more than 70 failures during the last 400 years (Fig. 1) with a remarkable increase starting from 1800 till now [8]. Due to intensive rainfall, peat landslides were triggered towards the later years of the 1900s. In Pollatomish in Ireland, 11 peat landslides occurred in 2003 within the peat soil mass. The estimated number of fatalities was 36 over the period 1600 to the present, which is equal to 0.1 victims per year. The interesting fact here is the mobility of peat soil failure, which travelled long distances from the failure source. For instance, in 1896, in Knockmageeha city in Ireland the failure extended 15 kilometres from its source, when the peat debris rapidly broke down into slurry and flowed within the drainage system as a viscous fluid which increased the risk of its movement.

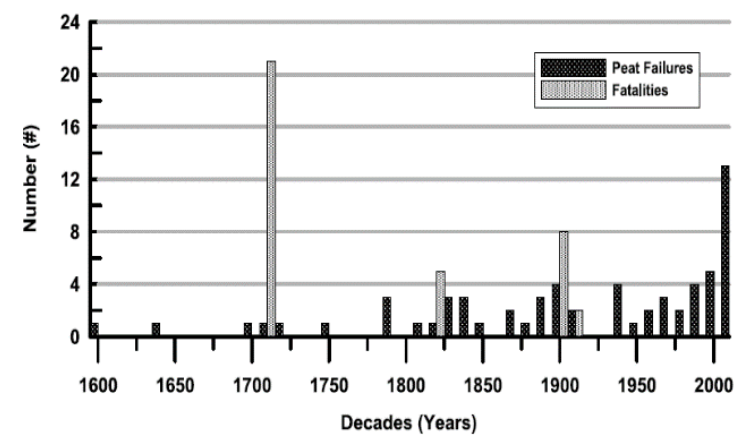

Fig. 1 Peat failures and fatalities in Ireland from 1600 to present [8].

Reference [8] has performed a study on the issues surrounding peat soil slope failure in Ireland which is of interest to engineers or engineering geologists assessing this geohazard. They stated that peat soil formation started in Ireland following the end of the Ice Age, some 10,000 years BP. It can be observed that moisture content ranged from $800 \%$ to $1300 \%$ where, the moisture content decreases with the increase of humification [9]. Linear shrinkage values from the study site decrease from close to $50 \%$ at $0.75 \mathrm{~m}$ to about $40 \%$ at $2 \mathrm{~m}$ depth, possibly reflecting the reduction in fibre content with depth. The bulk density of this site was 1.03 $\mathrm{Mg} / \mathrm{m}^{3}$. Reference [8] stated that there is a general tendency of increasing peat soil thickness with reduction in slope angle. Further, they found that the majority of the failures are clustered between $4^{\circ}$ and $8^{\circ}$. This may correspond to the slope angles, which allow a significant amount of peat to develop that over time becomes potentially unstable.

\subsection{Peat Occurrence in Italy}

The geotechnical properties of some Holocene alluvial deposits have been identified by [10] in the city of Rome. This city in Italy has long term of human activity and the original terrain have been continuously changed into an urban area. In Rome's historical centre, it becomes very difficult to recognise the original terrain due to the modification of the Tiber's right and left banks. Historically, this modification took place more than once and it has sometimes been effaced by construction and urban growth [11].

The right bank of the Tiber River, which hosts the Vatican, Monte Mario and Gianicolo, does not have geotechnical problems. This is because it mainly comprises of sand, silt and gravel (as coarse grains) as well as entirely lacking in an organic content. Therefore, the geotechnical properties are typically considered as consolidated soils with medium deformability [10]. The left bank soils, in contrast, are described as fine grained deposits with an abundance of silt and clay. Organic content and peat, which do not exist in the right bank, were found in the left bank deposits. Fosso di Grotta Perfetta, which is one of the Tiber River tributaries, comprises of up to $20 \%$ of organic-rich units which are on average about $5 \mathrm{~m}$ thick [10].

The difference between the right and left bank deposits reflects the variation in the geotechnical parameters and soil behaviour. Reference [5] stated that the organic content in clay is the main cause of its deformability and low strength. This was confirmed by [10] when they measured the geotechnical parameters for the left bank deposits as shown in Table 1. This displays a low shear resistance values with high levels of deformability in organic rich layers which are found in the alluvial deposits within the city of Rome.

The alluvial sediments in the Tiber River are subject to seismic amplification and the structure of organic-rich units are more 'sensitive' [12]. Such sediments are mostly under-consolidated, hence, more subject to settlement. Through data derived from some alluvial deposits in the City of Rome (including those of the Tiber), it is possible to identify areas potentially at risk from instabilities caused by the presence of organic matter [10]. 
Table 1 Geotechnical parameters of the lithotechnical units identified in Grotta Perfetta (Left Bank) deposits [10].

\begin{tabular}{|c|c|c|c|c|c|c|c|c|c|}
\hline Units & & $\begin{array}{c}\text { Average } \\
\text { thickness (m) }\end{array}$ & $\begin{array}{c}\gamma \mathrm{n} \\
(\mathrm{kN} / \mathrm{m} 3)\end{array}$ & $\begin{array}{c}\text { WC } \\
\% \\
\end{array}$ & LL\% & IP \% & $\varphi^{\prime}$ & $\begin{array}{c}\mathrm{C}^{\prime} \\
(\mathrm{kPa})\end{array}$ & $\begin{array}{c}\mathrm{Cu} \\
(\mathrm{kPa})\end{array}$ \\
\hline $\begin{array}{l}\text { Hist. } \\
\text { All }\end{array}$ & $\begin{array}{l}\text { Historical } \\
\text { floods }\end{array}$ & 3 & 16-19 & $32-65$ & $/ /-78$ & $\begin{array}{c}\text { NP- } \\
23\end{array}$ & $\begin{array}{l}30- \\
47\end{array}$ & $0-38$ & - \\
\hline $\mathrm{AM}$ & Brown clays & 7 & $15-19$ & $30-93$ & $43-123$ & $\begin{array}{l}17- \\
58\end{array}$ & $\begin{array}{c}23- \\
30\end{array}$ & $5-35$ & $21-74$ \\
\hline AO1 & Organic clays & 6 & $12-15$ & $\begin{array}{l}91- \\
186\end{array}$ & $\begin{array}{l}102- \\
171\end{array}$ & $\begin{array}{l}33- \\
93\end{array}$ & $\begin{array}{l}13- \\
22\end{array}$ & $9-25$ & $16-55$ \\
\hline AV & Green clays & 8 & $12-17$ & $\begin{array}{l}49- \\
154\end{array}$ & $84-151$ & $\begin{array}{l}24- \\
79\end{array}$ & $\begin{array}{l}17- \\
29\end{array}$ & $3-15$ & $7-19$ \\
\hline $\mathrm{AO} 2^{\prime}$ & Organic clays & 5 & $14-16$ & $\begin{array}{l}42- \\
184\end{array}$ & $63-164$ & $\begin{array}{l}18- \\
76\end{array}$ & $\begin{array}{l}13- \\
26\end{array}$ & $5-25$ & $15-33$ \\
\hline $\mathrm{AO} 2^{\prime \prime}$ & Organic clays & 15 & $16-19$ & $28-84$ & $46-104$ & $\begin{array}{l}17- \\
65\end{array}$ & $\begin{array}{c}25- \\
30\end{array}$ & $0-0.3$ & $15-30$ \\
\hline
\end{tabular}

// indicates no data.

\subsection{Peat Occurrence in Malaysia}

Malaysia has peat deposits observed predominantly along the coastal area (Fig. 2) except in Sri Aman [13]. These deposits occur at varying depths between 1 and $20 \mathrm{~m}$ [1]. The annual peaty soil's subsidence rate was predicted as $2 \mathrm{~cm}$ per year [14]. Concerns surround this subsidence, especially when acid sulphate soils which occur frequently underneath the peat soil, might surface. For more temperate regions, this subsidence rate was high for Malaysia compared with the rates in The Netherlands where the subsidence rate was the lowest in relation to ground water levels. The rates of subsidences in Indiana and Florida State were higher than those in The Netherlands. In Indiana, the subsidence rate was approximately $0.5 \mathrm{~cm} \mathrm{a}$ year; in contrast, the rate in Florida was some 1.4 cm a year [14].

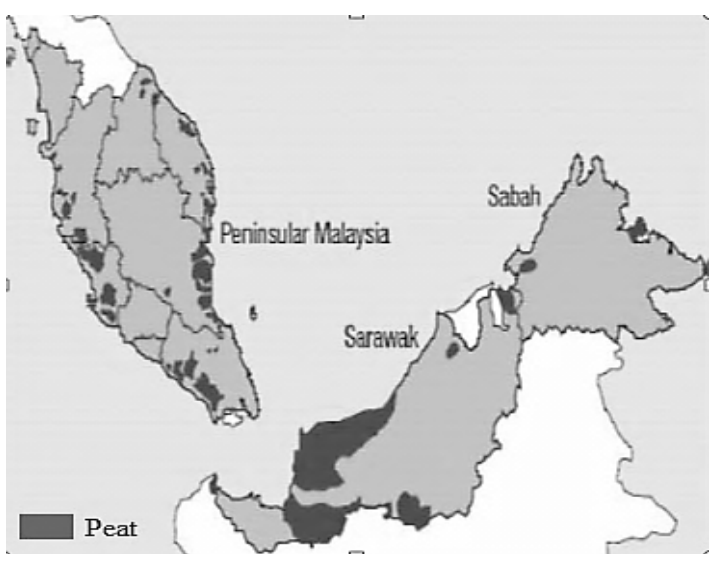

Fig. 2 Location of peat swamps in Malaysia (modified from [15]).

The result of the study in Malaysia shows that $60 \%$ of subsidence could be attributed to the oxidation and $40 \%$ to the peat soil shrinkage. Reference [16] have performed laboratory shear box tests in different locations in Malaysia. The result, as presented in Table 2, showed that cohesion values are between 6 and17 $\mathrm{kPa}$ and the friction angle is between 3 and $25^{\circ}$. Reference [1] stated that with the occurrence of more fibres in peat soil, the friction angle becomes higher. Also, shear strength parameters are lower with increasing degrees of humification (less fibrous).

Because Malaysia aspires to achieve a status of developed country by 2020, escalating infrastructure construction movement has been adopted. Based upon that, numerous projects are being erected on soft soils such as marine, organic and peaty soils because of lack of good ground conditions. A good example of these projects is Kuala Lumpur International Airport [13]. Peat soil, in Malaysia, is categorised as a tropical peat soil [3] and occurs along the coastal areas, especially in Sarawak where $16,500 \mathrm{~km}^{2}$ of its land is covered by dark reddish brown to black peat (about $89 \%$ of Sarawak's area) [13].

Peat soil problems and varying settlement rates have emerged in Malaysia. According to [13], serious diagonal fissures and cracks have been observed near windows, doors, and the opening of houses even during the process of construction. Moreover, the settlement rate surpasses $300 \mathrm{~mm}$ in the first year of construction; while, differential settlement observed exceeds 1:150 for the majority of buildings. The predicted settlement was 1440 $\mathrm{mm}$ for 3 months with $3 \mathrm{~m}$ surcharge and $2800 \mathrm{~mm}$ for 6 months.

Further, [17] and [18] have performed a study on in Sessang and Klang peat in Malaysia respectively. Numerous researches have been accomplished in an effort to characterise and stabilise the peat soil in Malaysia due to its wide occurrence as well as frequent subsidence and settlement problems. 
Table 2 Laboratory shear box test results of peat in different locations in Malaysia [16].

\begin{tabular}{lccccll}
\hline Location & MC & OC & LL & $\begin{array}{l}\text { Von } \\
\text { Post } \\
\text { Scale }\end{array}$ & $\begin{array}{l}\text { C } \\
\text { (kPa }\end{array}$ & $\varphi^{\prime}$ \\
& & & & & \\
& & & & & & \\
Banting, & 211 & 85 & 294 & H1 & $9-11$ & $9-20$ \\
Selangor & 195 & 79 & 219 & H2 & $6-11$ & $9-16$ \\
& 832 & 84 & 361 & H5 & $8-10$ & $7-10$ \\
& 219 & 94 & 316 & H6 & $11-$ & $9-12$ \\
& & & & & 12 & \\
& 225 & 85 & 166 & H8 & $8-12$ & $6-11$ \\
Kg. & 215 & 78 & 180 & H3 & $10-$ & $6-14$ \\
Jawa, & & & & & 12 & \\
Selangor & 209 & 89 & 325 & H6 & $12-$ & $7-25$ \\
& & & & & 14 & \\
& 786 & 85 & 368 & H8 & $7-11$ & $8-13$ \\
Kg. & 680 & 85 & 298 & H3 & $11-$ & $10-$ \\
Jawa, & & & & & 12 & 15 \\
Selangor & 747 & 93 & 352 & H5 & $10-$ & $5-10$ \\
& & & & & 12 & \\
& 720 & 83 & 282 & H7 & $7-9$ & $9-12$
\end{tabular}

\subsection{Peat Occurrence in the Netherlands}

In The Netherlands, the polder surface layers comprise soft organic clay and peat soil which are pressed upwards due to the potentially high level of the river. Therefore, the passive resistance of the inner slope will be reduced through the underlying sand layers. The delicateness of the peat and organic soils is problematic in tunnel construction when the tunnel cannot find underlying hard layers to settle [19].A canal dyke in Wilnis city in The Netherlands which comprises of peat soil failed in August 2003. This failure caused a partial an inundation of the downstream polder (Fig. 3). Dyke's body is represented by organic clay layers and soft peat soil which set down on the Pleistocene sand. The geotechnical parameters of the peat soil are presented in Table 3 . In the past, failure occurred as a result of decomposition and weathering of the peat soil as well as heavy rainfall after a long period of drought [19].

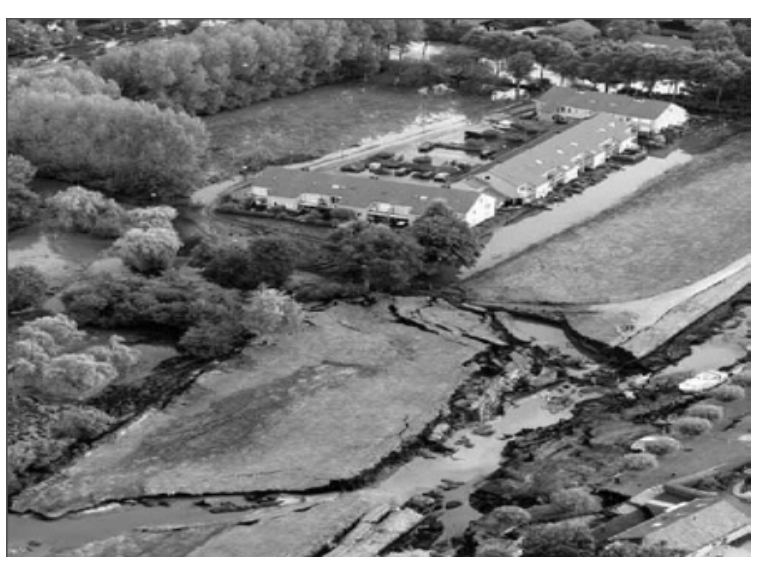

Fig. 3 Wilnis dyke the morning after [19].

In 2003, during the dry summer, the evapotranspiration caused a weight reduction and affected the marginal uplift stability of the dyke's toe at the downstream slope. Gaps occurred and enhanced along the wooden sheet pile due to lateral movement and shrinkage of the crest of the dyke. Therefore, hydraulic fractures occurred from the beginning of the wooden sheet pile to the underlying layer of sand.

Table 3 Properties of basal peat layer, Wilnis canal dyke [19].

\begin{tabular}{|c|c|c|c|c|c|c|c|}
\hline \multirow[t]{2}{*}{ Bore No } & \multirow{2}{*}{$\begin{array}{l}\text { Depth } \\
\text { (m) }\end{array}$} & \multirow{2}{*}{$\begin{array}{c}\rho \\
\left(\mathrm{t} / \mathrm{m}^{3}\right)\end{array}$} & \multirow{2}{*}{$\begin{array}{l}\mathrm{W}_{0} \\
\%\end{array}$} & \multirow{2}{*}{$\begin{array}{c}\sigma_{\mathrm{p}}{ }^{\prime} \\
(\mathrm{kPa})\end{array}$} & \multicolumn{2}{|c|}{ Estimated } & \multirow{2}{*}{$\begin{array}{c}\sigma_{\mathrm{v}} \\
(\mathrm{kPa})\end{array}$} \\
\hline & & & & & $\mathrm{e}_{0}$ & $\begin{array}{l}\sigma_{\mathrm{p}}{ }^{\prime} \\
(\mathrm{kPa})\end{array}$ & \\
\hline Oost-2-04 & 1.67 & 0.97 & 379 & 15 & 12.5 & 17 & 18.5 \\
\hline Oost-2-03 & 2.77 & 1.03 & 624 & 31 & 10 & 30 & 31 \\
\hline Oost-3-3BA & 3.8 & 1.01 & 511 & 40 & 8.5 & 45 & 42.5 \\
\hline Oost-3-2BA & 4.75 & 1.04 & 455 & 50 & 8 & 53 & 54 \\
\hline Oost-3-1BA & 6.8 & 1.05 & 450 & 68 & 7.8 & 56 & 71 \\
\hline
\end{tabular}


The dyke failed by lateral displacement because of the loss of shear resistance along the base of the peat and soft layers. This is due to an increasing uplifting pressure from the canal, mainly because a silty/loamy layer lies under the dyke materials thus enabled the hydraulic pressure to be directed under the dyke body (Fig. 4).

This dyke was laterally displaced between 5-8 m and $60 \mathrm{~cm}$ in length along the dyke section. Other possible factors and causes contributed to this failure, such as gas occurrence in the peaty base and Pleistocene sand which reduced the bulk density of those layers. Visually, gas was detected underneath by CPT camera sounding as an undissolved gas in the pores of the peaty soil. These pores were then formed by the decomposition of the peat soil. Therefore, materials in the underlying layers could be compacted and consolidated due to gas pressure causing in the higher yield stress, higher shear strength and reducing water content [19].

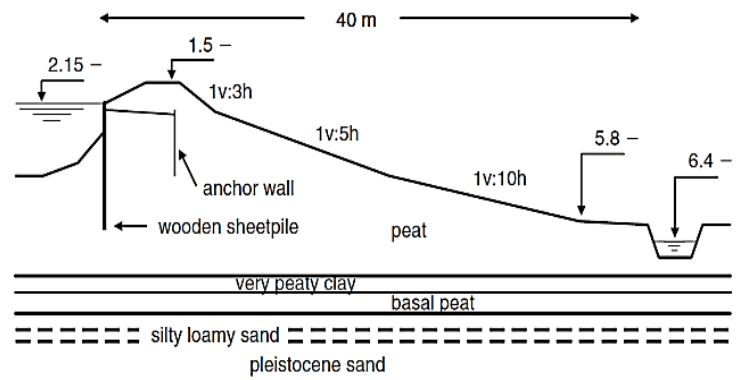

Fig. 4 Cross section of the Wilnis dyke [19].

Reference [20] computes the subsidence rate of peaty and non-peat soils in the eastern area of Amsterdam, Utrecht, Rotterdam and Den Haag in the Netherlands. They found that the predicted cumulative subsidence rate between 2005 and 2020 is over $80 \mathrm{~mm}$. On the contrary, this rate was 10 mm (over these 15 years) when peat was absent or thin in soil profile (Fig.11). This subsidence took place due to rising sea levels and tectonic subsidence of the western parts of the Netherlands [21]. As such, sea level rise due to climate change accelerates land subsidence through peat oxidation process [22].

\subsection{Peat Occurrence in Turkey}

Reference [23] stated that a huge industrial zone in Turkey known as (KOID) (Kayseri 1st Organised Industrial District) is suffering from cracks and fissures on the walls of structures. Surface ground deformation is happening underneath large and heavy metal framed buildings. This industrial zone extends over approximately 2,400 ha and was established in 1976. Now, KOID is considered as the largest and most well developed organised industrial zone in Kayseri city, central Anatolia in Turkey. This problem extends to the adjacent structures in the Kayseri Free Trade zone (KAYSER) which was established in 1998 on 690 ha over peat deposits. A geotechnical study was completed by [24] on the peat soil for the same area in 2007 when settlement of a rigid platform took place on the peat. Turkey has a 56,000 ha of peat lands [23].The peat soil thickness in this site in 22 boreholes was between $0-7.5 \mathrm{~m}$ which was confirmed by satellite images [23]. Other types of peat soil layers were found between $20-220 \mathrm{~m}$ as lignite (intermediate state between coal and peat) and Gyttja (a mud rich in organic matter found at the bottom or near shore or certain lakes).

SPT- $N$ values were between 3 - 4 blows, the peat's colour was dark brown to black, the soil was easily squeezed by hand, recognisable plant remnants, and water saturated. The natural water content was between 118 - 211\% at the top, while it ranged between 105 - 559\% for the peat soil from the boreholes. Other geotechnical properties for peat layers in Turkey fall within the ranges for peat soils from other countries [23]. The peat soil near the surface lies between $\mathrm{H} 3$ and $\mathrm{H} 4$ class as shown in Table 4, but when depth increases it lays between H5 and H7 according to the Von Post scale of humification.

Table 4 Physical and index properties of the peats in Turkey [23].

\begin{tabular}{lllllllll}
\hline Borehole No. & Depth (m) & Degree of Humification & W\% & $\begin{array}{c}\gamma_{\mathrm{b}} \\
\left(\mathrm{kN} / \mathrm{m}^{3}\right)\end{array}$ & $\begin{array}{c}\gamma_{\mathrm{d}} \\
\left(\mathrm{kN} / \mathrm{m}^{3}\right)\end{array}$ & $e$ & $\begin{array}{c}G_{\mathrm{s}} \\
(\%)\end{array}$ & $\begin{array}{c}\mathrm{LL} \\
(\%)\end{array}$ \\
\hline AC1 & $0.7-1.9$ & H3-H4 & 181.2 & 10.5 & 3.41 & 4.68 & 1.73 & 315.1 \\
AC2 & $0.7-2$ & H3-H4 & 135.8 & 11.4 & 4.49 & 3.35 & 2.13 & - \\
SK1 & $4.5-8.45$ & H5-H7 & 239.3 & 12.27 & 4.59 & 2.98 & 2.06 & 260.3 \\
SK2 & $0.5-6.95$ & H5-H7 & 322.6 & 13.8 & 6.26 & 2.19 & 1.98 & 147.5 \\
\hline
\end{tabular}




\subsection{Peat Occurrence in the USA, Indiana State}

Soils with high organic content are basically associated with unsatisfactory strength properties, high compressibility, and high rate of creep. This leads to unexpected problems such as foundation failure. One-dimensional compression behaviour of highly organic content soil has been tested by [25] in West Lafayette in the State of Indiana in the USA. The tested soil comprised of $40-60 \%$ organic material and represented a transitional material between inorganic clays and peat soil. Results have been found for this soil in both natural (intact) and reconstituted states according to the constant rate of strain and incremental loading of oedometer tests. As such, in terms of peat, the coefficient of consolidation values has decreased with the stress level increasing. In addition, the soil showed a significant tendency to creep with high end of values in compression index and secondary compression index which is consistent with what the literature reported for peat soils (Fig. 5). This therefore, demonstrates the highly variable nature of organic soils with geotechnical properties varying over a fairly wide range of specimens obtained in close proximity to each other [25]. As a long term problem, creep of infrastructures which are constructed over peat soil and organic soil deposits represents a major geotechnical problem. The creep rate of a soil can be determined by isopatche models which are uniquely dependent on effective vertical stress and strain [19]. To avoid this problem, pre-compression is used on a large scale to reduce settlement.

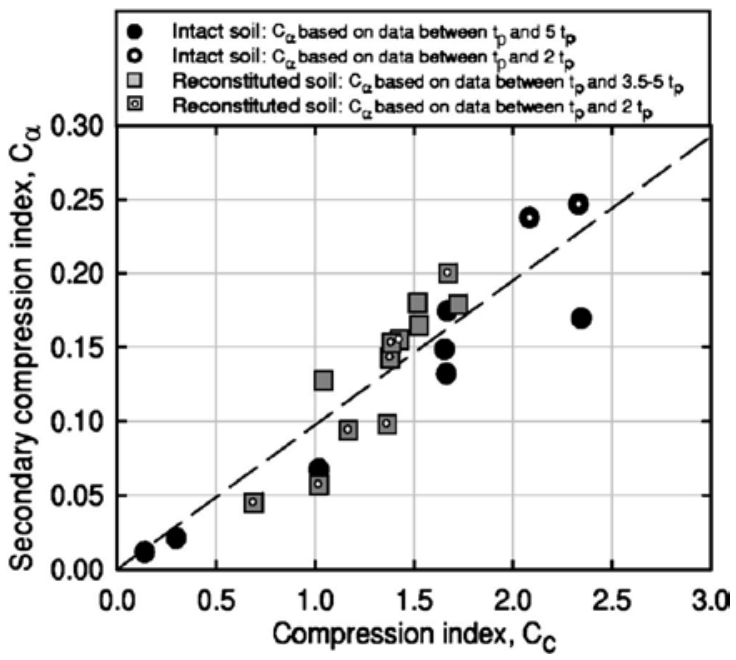

Fig. 5 Relationship between compression index and secondary compression index for intact and reconstituted organic soil [25]

\section{CASE STUDY IN SURFERS PARADISE, AUSTRALIA}

Surfers Paradise is a business and tourism hub of the Gold Coast, South East of the state of
Queensland, Australia. It has been an iconic tourist destination since the 1950s. Figure 6 shows the geographic location of the study area. Surfers Paradise has an area of about $4 \mathrm{~km}$ length by 1.3 $\mathrm{km}$ width. The reduced level used in this paper is based on the Australian Height Datum (AHD). The subsoil profile of Surfers Paradise consists of following layers:

- Loose to medium dense sand from the ground surface to R.L. $2.3 \mathrm{~m}$.

- Medium dense to dense sand is underlay from R.L. $2.3 \mathrm{~m}$ to R.L. $-3.2 \mathrm{~m}$.

- Very dense sand is encountered from R.L. $3.2 \mathrm{~m}$ to R.L. $-20 \mathrm{~m}$.

- Within the very dense sand layer, a varying thickness peat layer occurs at a depth of between R.L. -10 to R.L. $-19.6 \mathrm{~m}$ at different locations with thickness ranging from 0.1 $7.0 \mathrm{~m}$.

- Interbedded firm to very stiff clay layers are found up to R.L. -26.6 m where a layer of firm to hard clay occurs below it until the depth R.L. $-29 \mathrm{~m}$.

- The last layer of this soil profile varies within the study area where in some locations an interbedded layer of medium dense sand, gravelly sand, clayey sand, sandy clay, or hard silty clay can be observed.

This subsoil profile is consistent with the description given by [26] and [27]. The depth of the bed rocks in Surfers Paradise ranges from R.L. 27.3 to $-44.5 \mathrm{~m}$. The rocks are slightly to moderately weathered Argillite and Greywacke (sedimentary rocks) with moderately to high strong strength. Additionally, very strong Schist has also been encountered as bed rock in the Surfers Paradise area. This type of rock is a metamorphic rock which has been metamorphosed from clay. Furthermore, the water table is approximately 3.5 $\mathrm{m}$ below the ground surface as an average of all the locations within the study area.

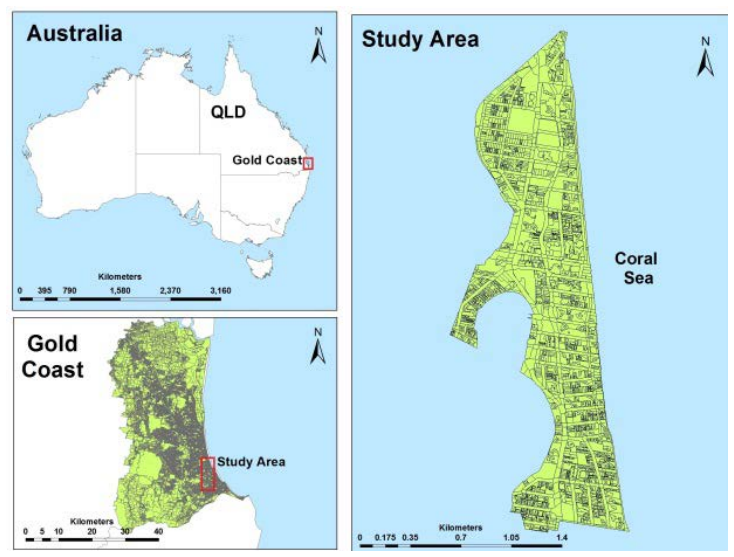

Fig. 6 Location of the study area in the Surfers Paradise, Australia 
Peat soil is located within the very dense sand layer in the Surfers Paradise soil profile. It is unconsolidated organic remains of plants that have partly fragmented and incompletely decomposed and in some locations decomposed.

According to [28], peat deposits have occurred on the Gold Coast region (where the study area is located) due to current and past marine processes near coastal zones. These marine deposits have been laid down ten thousand years ago during the Holocene geological period. As such, peat deposits which are found at $26.8 \mathrm{~m}$ in depth have been aged at $10,585 \pm 140$ years predating the present by using the radiocarbon method [29]. Obviously, peat deposits can be seen in three main types within the marine deposits: coastal swamp deposits which comprise of quartz sand and peaty quartz sand; dune lake deposits which contain sand and organic deposits, and beach swale deposits which include peat deposits overlying quartz sand [28].The physical and engineering properties of peat soil in Surfers Paradise have been presented in Table 5.

Table 5 Geotechnical parameters of peat soil in Surfers Paradise.

\begin{tabular}{|c|c|c|c|}
\hline Parameter & Values & Parameter & Value \\
\hline Liquid Limit & $259-305 \%$ & $\begin{array}{l}\text { Coeff. of Secondary } \\
\text { Consolidation }(\mathrm{C} \alpha)\end{array}$ & $0.03-0.04$ \\
\hline Plastic Limit & $125-207 \%$ & $\begin{array}{l}\text { Over Consolidation Ratio } \\
\text { (OCR) }\end{array}$ & $1.1-2.8 \%$ \\
\hline Plasticity Index & $88-134$ & Apparent Cohesion & $43-166 \mathrm{kPa}$ \\
\hline Water Content & $168-247 \%$ & Apparent Friction Angle & 0-14 Degree \\
\hline Unit weight & $1.14 \mathrm{t} / \mathrm{m}^{3}$ & Shear Strength & $30-40 \mathrm{kPa}$ \\
\hline Coeff. of Consolidation (Cv) & $\begin{array}{l}1.12-40.5 \\
\mathrm{~m}^{2} / \text { year }\end{array}$ & $\begin{array}{l}\text { Ash Content } \\
\text { Specific Gravity }\end{array}$ & $\begin{array}{l}20 \% \\
1.572\end{array}$ \\
\hline \multirow{2}{*}{$\begin{array}{l}\text { Coeff. of Volume } \\
\text { Compressibility (Mv) }\end{array}$} & 7.00E-05- & Permeability (k) & $1.40 \mathrm{E}-05-$ \\
\hline & $1.30 \mathrm{E}-04 \mathrm{~m}^{2} / \mathrm{kN}$ & & $2.40 \mathrm{E}-07 \mathrm{~m} / \mathrm{sec}$ \\
\hline Compression Index (Cc) & $1.83-2.74$ & $\begin{array}{l}\text { Organic Content } \\
\text { (estimated) }\end{array}$ & $63-68 \%$ \\
\hline
\end{tabular}

It can been seen from these properties that peat soil in Surfers Paradise has low shear strength (30-40 $\mathrm{kPa}$ ) and high moisture content (up to 247\%). Organic content has been estimated to be between 63-68 \%. The standard penetration test (SPT) $N$ values ranged between $0-19$. The high value of SPT-N in peat soil could be attributed to the occurrence of fibres within the peat structure.

Further, dry density of the Surfers Paradise peat soil decreases with the increase of water content (Fig. 7) and the empirical formula of this relationship is given in “Eq. (1)”.

Dry Density $=-0.0061 w+1.5635$

where $\mathrm{w}=$ Water Content

This is consistent with the trend of [30] for tropical peat soils in Malaysia and [31].

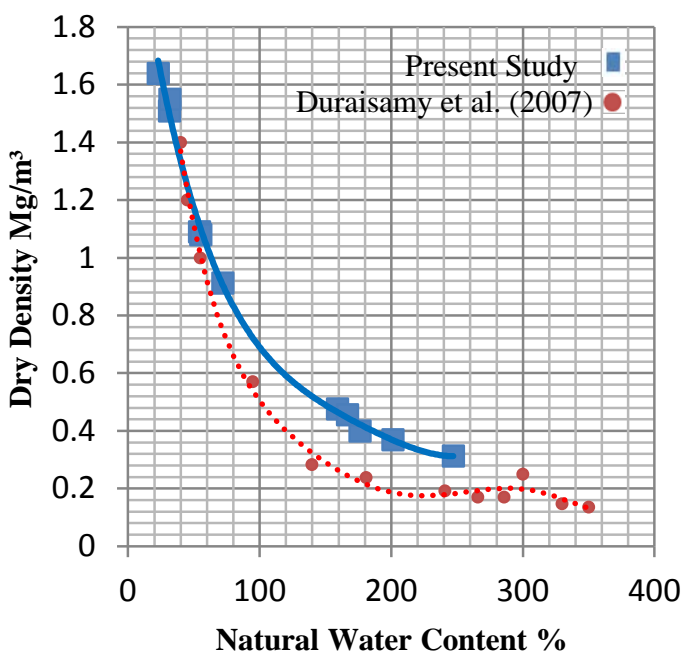

Fig. 7 Water content versus dry density in Surfers Paradise

Furthermore, an empirical formula has been established between the compression index and liquid limit (Fig. 8). This formula shows an 
increase in the compression index with the increase of liquid limit. Equation (2) shows the relation as follow:

$\mathrm{Cc}=0.0066 \mathrm{LL}-0.1603$

where $\mathrm{Cc}$ is the Compression Index and the $\mathrm{LL}$ is the Liquid Limit.

This relationship has been compared with [32] and [33] and showed similar trend to marine clay and peat soil respectively in Malaysia.

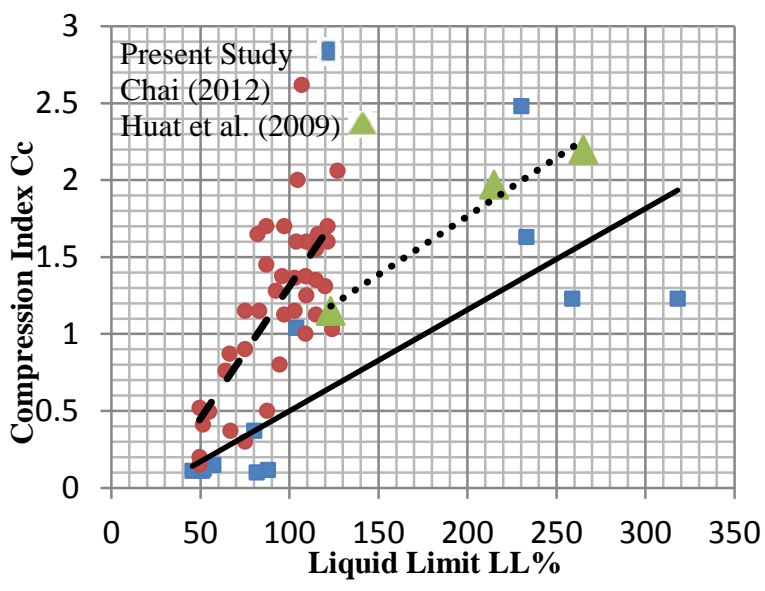

Fig. 8 Liquid limit and compression index correlation in Surfers Paradise.

In addition, a relationship between the liquid limit and water content has been plotted and the result as shown in Fig. 9. The outcome shows that with the increase of water content, the liquid limit increases. The correlation between them is presented in "Eq. (3)” and the $\mathrm{R}^{2}$ value is 0.92 .

$$
\mathrm{LL}=1.32 \mathrm{w}+8.614
$$

where LL = Liquid Limit, $\mathrm{w}=$ Water Content

This relationship is consistent with [33] for the peat soil in Malaysia, especially with Seri Medan, Kuala Langet, and Kuala-Sepetang peat soils. These peat soils have similar to higher values of liquid limit and moisture content.

Moreover, a relationship between water content and compression index has been established and the empirical formula is given in "Eq. (4)" as shown in Fig. 10. The $\mathrm{R}^{2}$ value of this formula is 0.66 . Also, a comparison between this study and [32] has been implemented.

$\mathrm{Cc}=0.01 \mathrm{w}-0.07$

where $\mathrm{Cc}=$ Compression Index, $\mathrm{w}=$ Water Content

This comparison showed that the marine clay of North-western Peninsular Malaysia has less water content than the Surfers Paradise peat soil. Correspondingly, the marine clay has high compressibility and higher water content than the Surfers Paradise clay. This comparison validates the relationship between Cc and W.C. in Surfers Paradise as it has the same trend to what [32] has found.

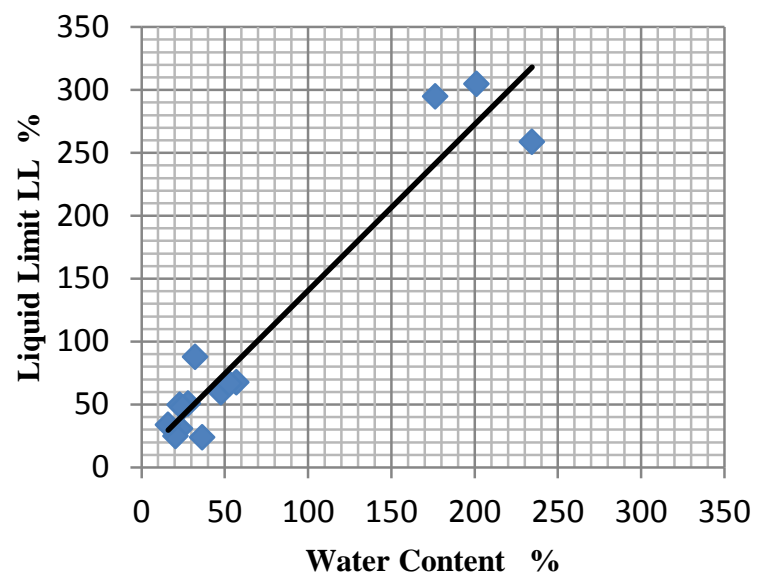

Fig. 9 Liquid Limit versus water content.

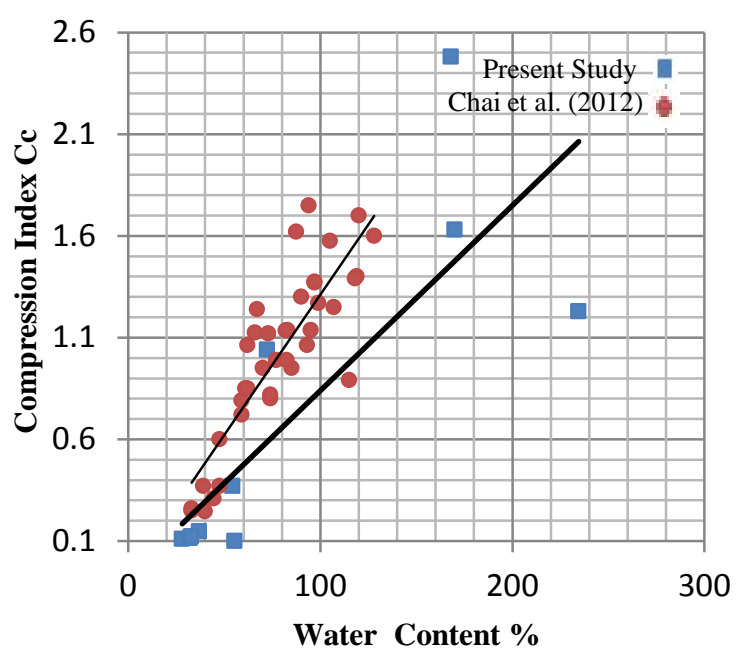

Fig. 10 Water content and compression index Cc correlation.

\section{CONCLUDING REMARKS}

This study investigated peat soil in different countries and different physical and engineering properties have been shown. High compressibility, low shear strength, and high moisture content are the main characteristics which define the peat soil worldwide. Further, this review has shown laboratory and field measurement of peat soil properties should be taken into account by geotechnical engineers to avoid unexpected foundation problems. Four empirical equations have been established for the peat soil in Surfers paradise. As a result, these formulae showed that this peat soil falls within the range of physical and engineering properties of peat soil in tropical regions. 


\section{REFERENCES}

[1] Huat, B.B.K., "Organic and Peat Soils Engineering”, Malaysia, Universiti Putra Malaysia Press, 2004.

[2] Landva, A.O., "Characterization of Escuminac peat and construction on peatland”, In Proc. of the 2nd Int. Workshop on Characterisation and Engineering Properties of Natural Soils, Singapore, 2007.

[3] Andriesse, J., "Nature and management of tropical peat soils”, FAO Soils Bulletin, Vol. 59, 1988.

[4] Radforth, N. W., "Muskeg as an engineering problem, Muskeg engineering handbook", Toronto, I. C. MacFarlane, Univ. of Toronto Press, 1969, 3-30.

[5] Malkawi, A.I.H., Alawneh, A.S., and AbuSafaqah, O.T., "Effects of Organic Matter on the Physical and the Physicochemical Properties of an Illitic Soil”, Applied Clay Science, Vol. 14, 1999, pp. 257-278.

[6] Kazemian, S., Huat, B., Prasad, A. and Barghchi, M., “A State of Art Review of Peat: Geotechnical Engineering Perspective”, International Journal of Physical Sciences, Vol. 6(8), 2011, pp. 1974-1981.

[7] Dykes, A.P. and Kirk, K.J., "Slope Instability and Mass Movements in Peat Deposits”, 16, Elsevier, 2006, In [12].

[8] Boylan, N., Jennings, P. and Long, M., "Peat Slope Failure in Ireland', Quarterly Journal of Engineering Geology and Hydrogeology, Vol. 41, 2008, 93-108.

[9] Hobbs N.B., "Mire Morphology and the Properties and Behaviour of some British and Foreign Peats”, Quarterly Journal of Engineering Geology and Hydrology, Vol. 19 (1), 1986, 7-80.

[10] Campolunghi, M.P., Capelli, G., Funiciello, R. and Lanzini, M., "Geotechnical Studies for Foundation Settlement in Holocenic Alluvial Deposits in the City of Rome (Italy)", Engineering Geology, Vol. 89, 2006, pp. 9-35.

[11] Capelli, G., 1999, Rapporti tra falda, reticolo idrografico e fognario nella Città di Roma. Giornata Mondiale dell'Ambiente, RomaNatura. Riserva Naturale di DecimaMalafede, 5 Giugno 1999- Relazione orale e poster.In [10].

[12] Monge, O., Chassagneux, D. and Mouroux, P., "Methodology for Liquefaction Hazard Studies: New Tool and Recent Applications", Soil Dynamics and Earthquake Engineering, Vol. 17(7-8), 1998, pp. 415-25.

[13]Zainorabidin, A. and Wijeyesekera, D., Geotechnical Challenges with Malaysian Peat, 2007, http://dspace.uel.ac.uk/jspui/handle/105 $\underline{52 / 785}$
[14] Wösten, J.H.M., Ismail, A.B. and van Wijk, A.L.M., "Peat Subsidence and its Practical Implications: a Case Study in Malaysia”, Geoderma, Vol. 78, 1997, pp. 25-36.

[15] Mutalib, A.A., Lim, J.S, Wang, M.H, and Koonvai, L., "Characterization, distribution and utilization of peat in Malaysia”. In Proc. of Int. Symposium on Tropical Peatland, 1991, pp. 7-8.

[16] Al-Raziqi, A.A., Huat, B.B.K., Munzir, H.A., "Potential Usage of Hyperbolic Method for Prediction of Organic Soil Settlement”, in $2^{\text {nd }}$ Int. Conf. on Advances in Soft Soil Engineering and Technology, 2003, pp. 439445.

[17] Abdullah, M., Huat, B. B.K, Kamaruddin, R., Ali, A.K. and Duraisamy Y., "Design and Performance of EPS Footing for Lightweight Farm Structure on Peat Soil”, American Journal of Applied Sciences, Vol. 4 (7), 2007, pp. 484-490.

[18] Hashim, R. and Islam, M.S., "Properties of stabilized peat by soil-cement column method”, Electronic Journal of Geotechnical Engineering, Vol. 13, 2008, pp. 1-9.

[19]Haan, E.J. and Kruse, G.A.M., "Characterisation and Engineering Properties of Dutch Peats", Characterisation and Engineering Properties of Natural Soils, Taylor \& Francis Group, London, Vol. 3, 2007, pp. 2101-2133.

[20] Hoogland, T., van den Akker, J.J.H. and Brus, D.J., "Modeling the Subsidence of Peat Soils in the Dutch Coastal Area”, Geoderma, Vol. 92-7, 2011, pp.171-172.

[21] Kooi, H., Johnston, P., Lambeck, K., Smither, C., Molendijk, R., "Geological causes of recent $(100 \mathrm{yr})$ vertical land movement in the Netherlands”, Tectonophysics, Vol. 299 (20), 1988, pp. 297-316.

[22] Remkes, J.W., d'Angremont, K., Donze, M., Feddes, R.A., Vellinga, P., Huisman, P., 2007. "Water en Bodemdaling in Groot-Mijdrecht. Rapport van de Onderzoekscommissie Water en Bodemdaling Groot-Mijdrecht Noord. Utrecht”, (in Dutch), in [20].

[23] Ulusay, R., Tuncay, E. and Hasancebi, N., "Geo-Engineering Properties and Settlement of Peaty Soils at an Industrial Site (Turkey)”, Bulletin of Engineering Geology and the Environment, Vol. 69 (3), 2010, pp. 397- 410.

[24] Sert S, Onalp A, "Settlements of rigid platform on peat and remediation". National symposium on soil-structure interaction in theory and practice, Istanbul, 2007, pp 181185 (in Turkish) in [27]

[25] Santagata M, Bobet A, Johnston C T, and Hwang J, "One-Dimensional Compression Behaviour of a Soil with High Organic Matter Content”, J of Geotechnical and 
Geoenvironmental Engineering, Vol. 134 (1), January 2008, pp.1-13.

[26] Oh, E.Y.N., Huang M., Surarak, C., Adamec, R. and Balasurbamaniam, A.S., "Finite Element Modelling for Piled Raft Foundation in Sand", in Eleventh East Asia-Pacific Conference on Structural Engineering \& Construction (EASEC-11) "Building a Sustainable Environment”, Taipei, Taiwan, 2008, 8.

[27] Al-Ani H, Oh E, Andargoli L, Chai G, "Subsurface Visualization of Peat and Soil by using GIS in Surfers Paradise, Southeast Queensland, Australia”, Electronic Journal of Geotechnical Engineering, Vol. 18, June 2013, Bund. I, pp. 1761-1774.

[28] Whitlow, R., TriMap Pty Ltd, “The Geology of the Gold Coast Region”, Report prepared for Gold Coast City Council, 2000, pp. 1-47.

[29] Thom, B.G. and Chappell, J., "Holocene sealevels relative to Australia”, Search, Vol. 6, 1975, 90-93.

[30]Duraisamy Y, Huat BBK, Aziz AA, "Engineering Properties of Compressibility Behaviour of Tropical Peat Soil”, American J of Applied Sciences, Vol. 4 (10), 2007, pp.768-773.
[31]Al-Ani H, Oh E, Chai G, "Engineering properties of peat in estuarine environment”, in in Proc. 1st Int. Conf. on Foundation and Soft Ground Engineering Challenges in Mekong Delta, 2013, pp. 181-191.

[32] Chai, GW, Mosavat, N, Oh, EY \& Loo, YC, "Characterization of Highly Compressible Marine Clay for Road Foundation”, Advances in Transportation Geotechnics 2, Taylor \& Francis Group, London, 2012, pp. 86-92.

[33] Huat BBK, Asadi A, Kazemian S, "Experimental Investigation on Geomechanical Properties of Tropical Organic Soils and Peat", American J of Engineering and Applied Sciences, Vol. 2 (1), 2009, pp.184-188.

Int. J. of GEOMATE, Sept., 2013, Vol. 5, No. 1 (Sl. No. 9), pp. 610-619.

MS No. 3114 received on May 21, 2013 and reviewed under GEOMATE publication policies. Copyright (c) 2013, International Journal of GEOMATE. All rights reserved, including the making of copies unless permission is obtained from the copyright proprietors. Pertinent discussion including authors' closure, if any, will be published in the Sept. 2014 if the discussion is received by March, 2014.

Corresponding Author: Haider Al-Ani 